\title{
Nonindustrial private forest owners' opinions to and awareness of energy wood market and forest-based bioenergy certification - results of a case study from Finnish Karelia
}

\author{
Pradipta Halder ${ }^{1 *}$, Timo Weckroth ${ }^{2}$, Qu Mei ${ }^{1}$ and Paavo Pelkonen ${ }^{1}$
}

\begin{abstract}
Background: Nonindustrial private forest owners (NIPFs) in Finland are important stakeholders of forest management and roundwood supply decisions. Their role will also be significant to supply energy wood to meet Finland's target for renewable energy in the future. The main objectives of this study were to explore the opinions and awareness of the Finnish NIPFs related to the energy wood market and forest-based bioenergy certification issues in Finland and their relevance for future bioenergy policies.

Method: A questionnaire-based survey was conducted among the NIPFs in Finnish Karelia $(N=79)$.

Results: The Finnish NIPFs considered price as the key deciding factor in harvesting and selling of energy wood. The present low price of energy wood compared to pulpwood did not motivate them to increase harvesting and selling of energy wood from thier forest estates. The majority of them appeared to be unaware of the Criterion 5 under the PEFC group forest certification scheme, which provides guidance on harvesting of biomass from forests for energy production in Finland. However, they expected that forest-based bioenergy certification schemes should be easy to follow, develop energy wood market, and promote environmentally sound forest management practices in Finland. Private forest owners' associations and personal information letters emerged as the most favored means to disseminate information on forest-based bioenergy certification to the Finnish NIPFs.
\end{abstract}

Conclusions: The study explored the opinions and awareness of the Finnish NIPFs related to energy wood market and forest-based bioenergy certification issues. The conclusions derived from the study might be highly policy-relevant concerning the development of energy wood market and related certification schemes. Future studies should include larger sample size for increasing the representativeness of the findings.

Keywords: Nonindustrial private forest owners, Energy wood market, Bioenergy certification, Finnish Karelia

\section{Background}

Finland is a heavily forested country and currently one of the leading countries in the world in producing woodbased bioenergy, which accounts for one-fifth of the total energy production in Finland [1]. Nonindustrial private forest owners (NIPFs) including private individuals, families or heirs own $60 \%$ of the forest land; government owns $26 \%$; forest companies own $9 \%$; and municipalities, church

\footnotetext{
* Correspondence: pradipta.halder@uef.fi

${ }^{1}$ School of Forest Sciences, University of Eastern Finland, Joensuu 80101, Finland

Full list of author information is available at the end of the article
}

parishes and other collective bodies own the remaining $5 \%$ [2]. At the end of 2008, there were 344,559 privately owned forest estates in Finland, while the number of NIPFs was 734,734 with forest estates larger than 2 ha [2]. It indicates that a single forest estate can be owned jointly by a NIPF with his or her family members. The role of the NIPFs in Finland is important not only due to the high percentage of forest land under their ownerships, providing $80 \%-90 \%$ of the domestic roundwood used by the forest industries, but also for their diverse objectives, attitudes and interests that appear to influence their forest management decisions [3]. 
It has been argued that the excessive removal of biomass residues from the forests in Finland and other Nordic countries can affect forest biodiversity, reduce nutrient balance in forest soil, and affect the cultural practices of local people [4]. These concerns have resulted in the increasing relevance of developing of bioenergy certification schemes with distinct criteria and indicators ( $\mathrm{C}$ and $\mathrm{I}$ ) to measure sustainability of the bioenergy production systems including biomass production from forests [5]. More than 95\% of the Finnish forests are certified by the Programme for Endorsement of Forest Certification (PEFC) [6], whereas the area of the Forest Stewardship Council (FSC)-certified forest is only a fraction of the PEFC-certified forests in Finland. The figures of certified forests under either the PEFC or FSC scheme in other Nordic countries stand at $40 \%$ in Denmark, $80 \%$ in Sweden, and almost 100\% in Norway $[7,8]$. In comparison to forest certification, $\mathrm{C}$ and I for bioenergy and related certification issues have emerged very recently in Finland. Though Finland has no forestbased bioenergy certification scheme at present time, the general guidelines for sustainable energy wood harvesting remain under the PEFC Criterion 4 and 5 for individual and group ownerships of forest, respectively [9]. Some of the principles under these Criteria are the following: peat lands in their natural state shall not be used for energy wood cultivations; endangered species shall be safeguarded while harvesting energy wood; harvest of energy wood shall not substantially deteriorate the protection values of protected areas and endanger the preservation of monuments of antiquity; and biomass harvesting shall take into consideration the wood production capacity of the site, biodiversity, and water protection. The Forestry Development Centre Tapio in Finland has modified the PEFC guidelines for energy wood harvesting into general recommendations for harvesting and producing energy wood [10].

Economic viability, environmental performance, and social acceptability are generally recognized as the three criteria to evaluate sustainability of bioenergy projects. However, a comprehensive set of $\mathrm{C}$ and I for bioenergy production from forest that can be integrated with the current systems of $\mathrm{C}$ and I for sustainable forest management is still lacking [11]. Recently, the European Commission has formulated the binding sustainability criteria for biofuels and bioliquids for the transport sector under the Renewable Energy Directive (RED) [12]. The Commission has also published a report directly built upon the RED that is related to the sustainability requirements for the use of solid and gaseous biomass sources in electricity, heating, and cooling [13]. Although there are concerns over the negative impacts of the RED on indirect land-use change (iLUC), Havlik et al. [14] have reported that the second-generation biofuel production fed by wood from sustainably managed forests would lead to a negative iLUC factor (i.e., much lower emissions compared to 'no biofuel scenario' by 2030). However, the Commission has decided against any binding criteria for solid and gaseous biomass-based bioenergy systems until date.

Apart from the RED, several other policy initiatives have been directed towards developing solid biofuel standards. In this regard, a recently completed project Bioenergy Promotion (www.bioenergypromotion.net) has formulated a policy guidance paper known as 'Sustainable bioenergy production: defining principles and criteria' [15]. The guidance paper covers six broad principles (viz., biodiversity, resource efficiency, energy efficiency, climate mitigation efficiency, social, and economic aspects) and includes specific $C$ and I, covering all types of bioenergy under each of the six principles. The European Union, the Norwegian Government, and the national authorities of the partner countries from the Baltic Sea Region funded the project, while the Swedish Energy Agency was the coordinator. Similarly, Food and Agricultural Organization of the United Nations [16] has also published a comprehensive set of $\mathrm{C}$ and I for sustainable wood fuels. Although these initiatives have the potential to contribute to the forest-based bioenergy sector, there appears to be limited information available on their acceptability among the different stakeholders involved in wood-based bioenergy development.

The supply of biomass from forests to energy producers is a challenging issue in various parts of the world where NIPFs play an important role in supplying raw materials to forest-based industries. Therefore, understanding the opinions of the NIPFs is a one-key issue in ensuring the future supply of woody biomass to the bioenergy industries in Finland and similar countries. There have been a small number of studies in USA and Europe on exploring NIPFs' perceptions of forest-based bioenergy. In the USA, NIPFs were found to be willing to supply wood and forest residues for bioenergy production, and their willingness was positively correlated with their perceived increase in the price of biomass [17-19]. However, those NIPFs also considered several barriers in energy wood harvesting and supply such as lack of ready energy wood market and lack of efficient logistics [18]. Regarding policy issues, the American NIPFs favored support from the government in the form of tax incentives over direct subsidies [20]. In Sweden, it was found that the NIPFs were concerned over the loss of soil nutrient due to intensive harvesting of energy wood and for that concern, many of them refrained from selling energy wood [21]. In Finland, Rämö, et al. [22] reported Finnish NIPFs' positive attitudes to the use of wood and agricultural crops in energy production. They also reported a state of uncertainties among the Finnish NIPFs in their willingness to supply biomass, owing to 
their ignorance of energy wood production and market in Finland. However, the Finnish NIPFs also reported their concerns over the loss of soil fertility due to excessive harvesting of forest residues for energy production [22].

In 2008, the energy sector was alone responsible for $78 \%$ of the greenhouse gas emissions in Finland [23]. Therefore, using renewable energies particularly wood fuels is important for the future Finnish climate and energy policies. Although a recent study by Wibe [24] has reported that the carbon neutrality of wood fuel is only true in the very long run, the use of wood fuels particularly wood chips has been projected to increase in Finland in both short and medium terms to meet the country's target of $38 \%$ renewables in the total energy consumption by 2020 under the RED [25]. This indicates that there would be an increasing societal demand for producing certified biomass for energy production. At the same time, such certification schemes should also ensure the supply of biomass, price transparency, and fulfillment of sustainability requirements [26]. In this context, the role of the Finnish NIPFs will be important to meet this additional demand for forest chips for energy production in Finland. Therefore, it is highly relevant to explore the opinions and awareness of the Finnish NIPFs to this future trend, including forestbased bioenergy certification issues.

\section{Aims of the study}

The broader aims of this study were to explore the opinions and awareness of the Finnish NIPFs towards energy wood market and forest-based bioenergy certification issues and to derive recommendations for such certification schemes in order to gain acceptance from the Finnish NIPFs in the future. Specific research aims of the study were as follows:

(1) to find out the opinions of the Finnish NIPFs towards energy wood market in Finland,

(2) to explore the Finnish NIPFs' awareness of and opinions to forest-based bioenergy certification issues, and

(3) to find out the most favored organization as well as the method for disseminating information on forestbased bioenergy certification among the Finnish NIPFs.

\section{Methods}

\section{Case study area}

Finnish Karelia, which consists of the two regions North and South Karelia, was selected for this study in order to have the study area representative of the average Finnish circumstances in forestry and with NIPFs' characteristics. For example, forests cover $80 \%$ of the land area of Finnish Karelia, whereas such figure for whole Finland is
73\%; average forest-land holdings of the NIPFs in Finnish Karelia is about 24 ha, whereas the Finnish national average is 23.6 ha; and the total number of the NIPFs in Finnish Karelia with forest holdings of at least two ha is about 31,000 , which is almost $11 \%$ of the total number of the NIPFs in Finland with similar profile [27]. In addition, Finnish Karelia harbors some of the largest forest industries in Finland, which indicates that the NIPFs in this region are important to those forest industries for supplying wood materials.

\section{Data collection and analysis}

Prior to the final survey, a pilot survey was conducted with an initial form of the questionnaire among a group of the NIPFs in Finnish Karelia. Their feedback on the questionnaire and suggestions by the bioenergy experts at the School of Forest Sciences within the University of Eastern Finland contributed to improve the final version of the questionnaire. The final data for the study came from a mail survey conducted in May 2010 among 400 NIPFs in Finnish Karelia. The questionnaires were sent to the NIPFs in sealed mailing envelopes, which also included a cover letter describing the purpose of the survey and a self-addressed return envelope. The cover letter mentioned a 1-month time for returning the completed questionnaire from the date of delivery of the questionnaire to the respondent. This mailing procedure was selected since the similar method was also used in Finland in a previous study among the Finnish NIPFs [22]. In addition, this method was also recommended to be followed by the regional forestry centers in Finnish Karelia. The NIPFs were randomly selected through a mailing list provided by the regional forestry centers in Finnish Karelia. The mail survey produced 79 complete responses amounting to a $20 \%$ response rate. All the responses were obtained between May and June 2010 within the stipulated time frame.

The survey questionnaires administered among the NIPFs were in Finnish and the researchers did the translation back into English for the analysis. In terms of ethical consideration, the study informed the NIPFs that their answers would be treated with absolute confidentiality. The NIPFs participated in the study voluntarily and prior approval for the survey was obtained from the regional forestry centers in Finnish Karelia. Furthermore, neither email addresses nor phone numbers of the NIPFs were provided to the researchers by the regional forestry centers according to their standard procedures. Therefore, it was not possible to contact the nonrespondents to analyze any possible biases in the results as the response rate appeared to be quite low in the study.

The self-constructed questionnaire of the study consisted of close-ended items in three categories: (1) sociodemographic profile of the NIPFs, (2) background 
information on their forest estates including utilization and selling of energy wood, and (3) their awareness of and opinions to energy wood market including forestbased bioenergy certification issues. A separate piece of paper describing the PEFC Criterion 5 related to energy wood harvesting in Finland was attached to each questionnaire. The main reason for selecting the PEFC Criterion 5 was due to the wider adoption of the PEFC group certification system in Finland including the Finnish Karelia. The key questions that have been analyzed for this study are included in Additional file 1. The quantitative analysis has been performed with the help of SPSS ( $v$ 17.0).

\section{Results}

\section{Profile of the NIPFs}

The representation of the NIPFs in this study appeared to be biased towards the male NIPFs, as the female participation was only $15 \%$. The average age of the NIPFs along with their educational and employment status showed similarities with the findings by Rämö et al. [22]. In this study, the average size of the forest estate was found to be 73 ha, which was much higher than the average in Finnish Karelia, which is 24 ha. This higher average of forest land holding resulted as the NIPFs in this study were asked to report their total forest area including the area jointly owned with their spouses and other family members. However, official Finnish statistics, as well as the previous studies, always reported this figure based on the average of individual ownerships. In addition, $13 \%$ of the NIPFs in this study reported to have forest estates equal to or more than $100 \mathrm{ha}$, which also increased the average size of their forest holdings. Excluding this $13 \%$, the average forest area became 45 ha, which was almost similar to the figure of 47 ha that was reported in the study by Rämö et al. [22]. Only $1 \%$ of the NIPFs in this study reported to have nature conservation areas in their forest estates.

About $83 \%$ of the NIPFs reported to have used wood for heating their households and business premises, whereas only $29 \%$ of the NIPFs sold energy wood from their forest estates in the form of firewood, round wood, and wood chips. Average utilization and selling of energy wood stood at 20 solid $\mathrm{m}^{3}$ and 200 solid $\mathrm{m}^{3}$ respectively. The study did not find any relationship between the NIPFs' size of forest estates and their selling of energy wood. However, only the male NIPFs informed that they sold energy wood from their forest estates. The background information of the NIPFs in the present study is provided in Table 1.

\section{NIPFs' opinions to the energy wood market in Finland}

The NIPFs were asked to inform their opinions to the competition between supply of energy wood and pulpwood in Finland. The majority of them (65\%) perceived such competition at a low level, while $35 \%$ of them
Table 1 Profile of the NIPFs in the study

\begin{tabular}{|c|c|}
\hline Profile & NIPFs of this study \\
\hline Number of NIPFs responded & 79 \\
\hline Average age & 59 years \\
\hline Gender & Men-85\%; Women-15\% \\
\hline \multicolumn{2}{|l|}{ Level of education } \\
\hline Grade school & $25 \%$ \\
\hline Vocational school & $39 \%$ \\
\hline $\begin{array}{l}\text { Higher education (including polytechniques } \\
\text { and university) }\end{array}$ & $36 \%$ \\
\hline \multicolumn{2}{|l|}{ Status in employment } \\
\hline Employee (public and private) & $26 \%$ \\
\hline Agriculture/forestry entrepreneur & $26 \%$ \\
\hline Pensioner & $44 \%$ \\
\hline Other & $4 \%$ \\
\hline \multicolumn{2}{|l|}{ Status of forest, energy wood use, and trade } \\
\hline Average size of the forest estates & $\begin{array}{l}73 \text { ha (min } 1 \text { ha, } \\
\max 500 \text { ha) }\end{array}$ \\
\hline Average area of forest under timber production & $\begin{array}{l}72 \text { ha (min } 1 \text { ha, } \\
\max 450 \text { ha) }\end{array}$ \\
\hline $\begin{array}{l}\text { Average use of wood for heating } \\
\text { household and business by the NIPFs }\end{array}$ & $\begin{array}{l}20 \text { solid } \mathrm{m}^{3}\left(\min 1 \mathrm{~m}^{3},\right. \\
\left.\max 300 \mathrm{~m}^{3}\right)\end{array}$ \\
\hline Average selling of energy wood by the NIPFs & $\begin{array}{l}200 \text { solid } \mathrm{m}^{3}\left(\min 9 \mathrm{~m}^{3},\right. \\
\left.\max 842 \mathrm{~m}^{3}\right)\end{array}$ \\
\hline
\end{tabular}

expressed their lack of knowledge of that issue. However, none of them considered the competition was high. About $60 \%$ of the NIPFs perceived the price of energy wood at a much lower level compared to the price of pulpwood in Finland. About 11\% of the NIPFs perceived the two prices at the same level. However, remaining one third of the NIPFs informed that they did not know about the price differences between energy wood and pulpwood. The majority of the NIPFs (92\%) informed that price would be the most important factor while selling energy wood in the market, whereas environmental concerns and national interests (economy, energy security, etc.) were considered by the remaining $8 \%$ of the NIPFs (Figure 1).

The study intended to explore whether the NIPFs would increase harvesting and selling of energy wood from their forest estates if there would be a stable energy wood market in Finland besides the traditional paper and pulp wood market. Only $6 \%$ of the NIPFs appeared to be in favor of increasing harvesting and selling of energy wood from their forest estates in the presence of a stable energy wood market in Finland. However, the majority of them (73\%) appeared to be reluctant to participate in that activity, while about $20 \%$ of the NIPFs remained undecided on that issue.

About 53\% of the NIPFs considered the price of energy wood as the most important obstacle in the trade of 


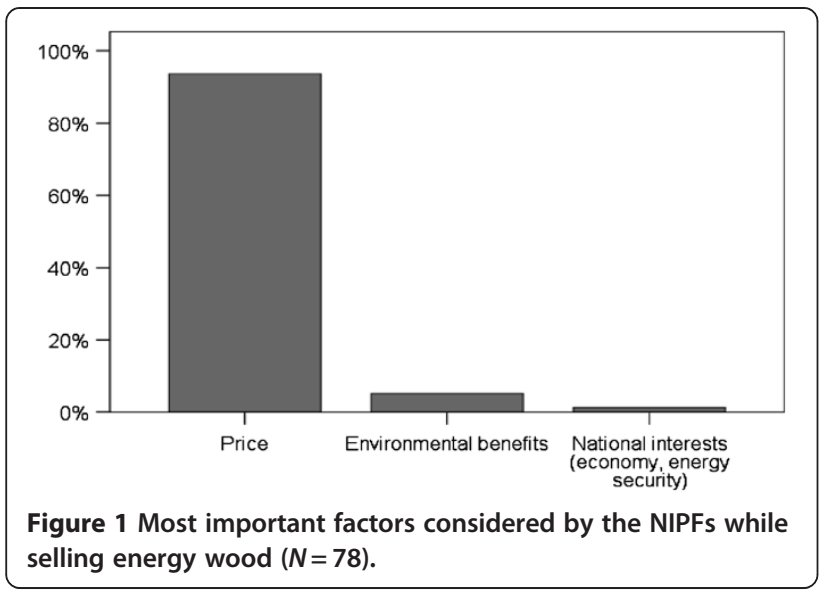

energy wood as it was low. Logistics was considered as another challenging issue in energy wood trade $36 \%$ of the NIPFs. About $2 \%$ of the NIPFs considered the legal and administrative issues as other obstacle in the trade of energy wood. The majority of the NIPFs (70\%) favored the Finnish government to take measures to remove the obstacles in the energy wood market, whereas $28 \%$ of them remained undecided on that issue. Gender and level of education appeared to have statistically significant effects on the NIPFs' opinions to this governmental intervention. The female NIPFs $(z=2.41$, $p$ value $=.015)$ and the NIPFs with lower level of education $(z=2.99, p$ value $=.003)$ were more in favor of government interventions in energy wood market compared to the males and the NIPFs with higher education.

\section{NIPFs' awareness of and opinions to forest-based bioenergy certification}

The NIPFs were asked to inform whether their forests were under the PEFC scheme. However, only $42 \%$ of the NIPFs confirmed that their forests were under that scheme, whereas 19\% denied and the remaining 39\% informed their lack of awareness of the status of their forests under the PEFC scheme. In a subsequent question, the respondents were asked to inform whether their forests were certified under the FSC certification scheme. Only one respondent confirmed, while $48 \%$ of them denied and the rest informed their ignorance of that issue.

Another question explored the NIPFs' awareness of the Criterion 5 in the Finnish PEFC group Certification scheme, which contained guidelines for energy wood harvesting. Only $17 \%$ of the NIPFs appeared to be aware of those guidelines, while the majority (83\%) was not aware of that Criterion 5. It appeared that only $26 \%$ of the NIPFs who informed that their forests were certified by the PEFC scheme were aware of the Criterion 5 . The description of the Criterion 5 was also supplied with the survey questionnaires so that the NIPFs were able to observe those guidelines and could express their opinions related to the usefulness of those guidelines for energy wood harvesting. About $14 \%$ of the NIPFs considered those guidelines as useful, 25\% did not consider them as useful, while the remaining $61 \%$ expressed their inability to evaluate those guidelines in terms of their usefulness. It was also found that more than half of the NIPFs who were aware of the Criterion 5 considered those guidelines as not useful.

The NIPFs were asked to select one from a list of three options indicating the most important quality of a forest-based bioenergy certification scheme. About 45\% of them selected the option which suggested that such scheme should be practical and easy to follow; $38 \%$ of the NIPFs selected the option, which suggested that such certification scheme should improve market conditions for energy wood in Finland (Figure 2). The remaining $17 \%$ selected the option that indicated the protection of forest biodiversity.

About 55\% and 59\% of the NIPFs agreed respectively on the usefulness of the forest bioenergy certification schemes to improve environmental-friendly forest management practices and marketing possibilities of forest biomass for energy production in Finland (Table 2). However, about one third of the NIPFs remained undecided on this matter, while $10 \%$ of the respondents were not in the agreement with the majority in terms of the usefulness of forest bioenergy certification.

In another question, the NIPFs were asked about the present state of awareness of forest-based bioenergy certification among the Finnish NIPFs. About 39\% of the NIPFs considered such awareness as growing among the Finnish NIPFs, while $11 \%$ of them had opposite thoughts. However, almost half of the NIPFs informed that they did not know about the state of awareness of such certification schemes among the Finnish NIPFs.

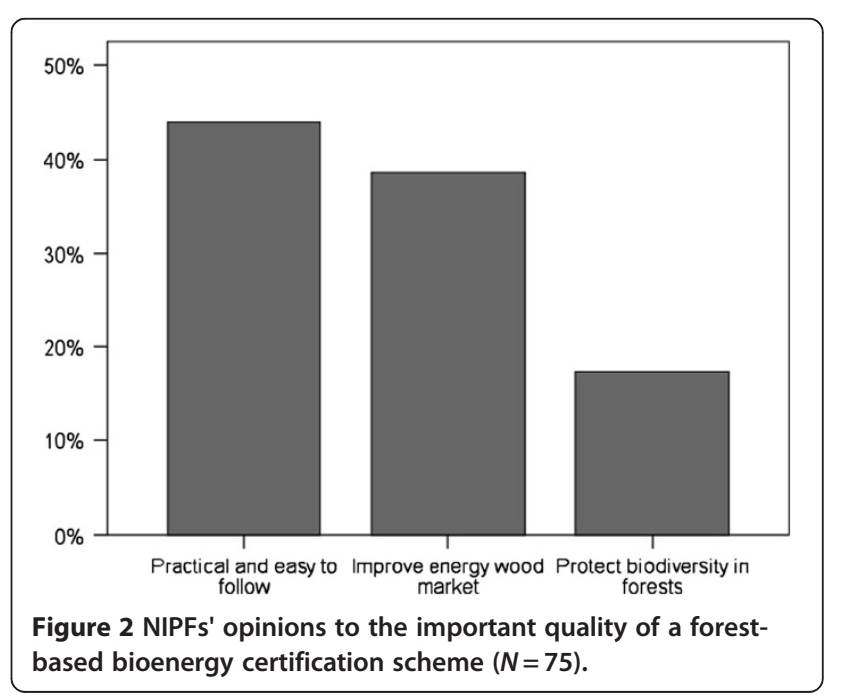


Table 2 Finnish NIPFs' agreement and disagreement with the usefulness of forest bioenergy certification

\begin{tabular}{|c|c|c|c|c|c|}
\hline Questionnaire items & $\begin{array}{l}\text { Strongly } \\
\text { agree }(\%)\end{array}$ & Agree (\%) & Disagree (\%) & $\begin{array}{l}\text { Strongly } \\
\text { disagree (\%) }\end{array}$ & Neutral (\%) \\
\hline $\begin{array}{l}\text { Forest bioenergy certification can increase environmental- friendly } \\
\text { forest management practices in Finland }(N=79)\end{array}$ & 9 & 50 & 6 & 3 & 32 \\
\hline $\begin{array}{l}\text { Forest bioenergy certification can improve private forest owners' marketing } \\
\text { possibilities of forest biomass for bioenergy production }(N=79)\end{array}$ & 7 & 48 & 7 & 4 & 34 \\
\hline
\end{tabular}

Age, gender, and level of education did not appear to have any statistically significant effects on the Finnish NIPFs' awareness of and opinions to the forest-based bioenergy certification issues.

\section{Dissemination of information on forest-based bioenergy certification}

There were two questions, which aimed to explore the opinions of the NIPFs towards the most suitable organization and method for disseminating information on forest-based bioenergy certification to the NIPFs in Finland. The majority of the NIPFs considered the regional private forest owners' associations as the most suitable organizations for such dissemination activity. Their considerations for the regional forestry centers, research organizations, and forest industry were at a much lower level compared to the private forest owners' associations (Figure 3). In terms of the method for disseminating information, half of the NIPFs opined that the personal information letters delivered by the regional private forest owners' associations would be the most suitable method for disseminating information on forestbased bioenergy certification (Figure 4). Other methods such as newspapers and magazines, television, the internet, and radio did not receive much support from the Finnish NIPFs. Like the above factors, age, gender, and level of education did not appear to have any statistically

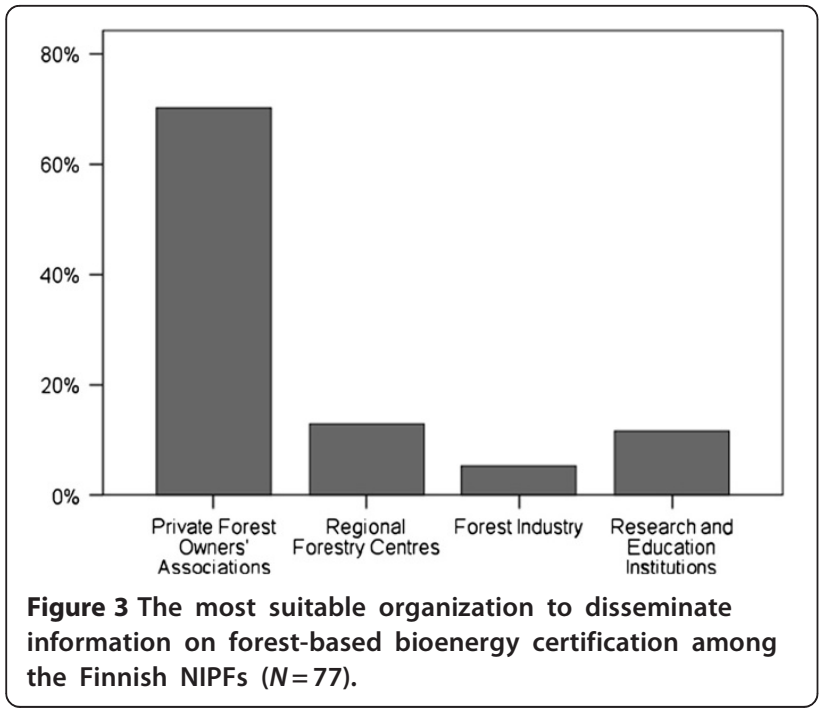

significant effects on the Finnish NIPFs' opinions to the dissemination of information related to forest-based bioenergy certification.

\section{Discussion}

The aims of the study were to explore the opinions and awareness of the Finnish NIPFs related to energy wood market and forest-based bioenergy certification issues in Finland. In addition, the study aimed to highlight some key considerations that the future forest-based bioenergy certification schemes should take into account to gain acceptance from the Finnish NIPFs. The study found that the use of energy wood was common among the NIPFs for their own household purposes, although only one third of them sold energy wood into the market. This lack of participation of the Finnish NIPFs in the energy wood business was perhaps due to the low price of energy wood and an almost nonexisting market for such product in Finland. This reflected that the much-debated competition between the supply of wood for energetic use and for other purposes was not a reality in the Finnish context until the present day.

In general, the findings suggested the price of energy wood as the most important factor for the NIPFs' interests in selling energy wood. Lower price of energy wood compared to pulpwood did not encourage the majority of the Finnish NIPFs to increase harvesting and selling energy wood from their forest estates. However, it was interesting to find out that the Finnish NIPFs did not consider increasing the supply of energy wood from their forest estates even if there would be a stable market for such products in Finland in the future. In this case, the findings of this study differed from the study by Markowski-Lindsay et al. [19] who found that the American NIPFs were willing to harvest forest biomass for energy production given a higher price for such materials. Perhaps the Finnish NIPFs did not perceive positively the future developments in the energy wood market in Finland and they favored a wait and see approach concerning this issue. However, it should be noted here that due to the Finnish energy wood policy, the use of energy wood for heating by the NIPFs in their households is expected to increase in Finland [28], and this growth seems to continue regardless of the price and market issues related to energy wood.

Besides the pricing issue, technical challenges such as logistics emerged as an important obstacle for the 


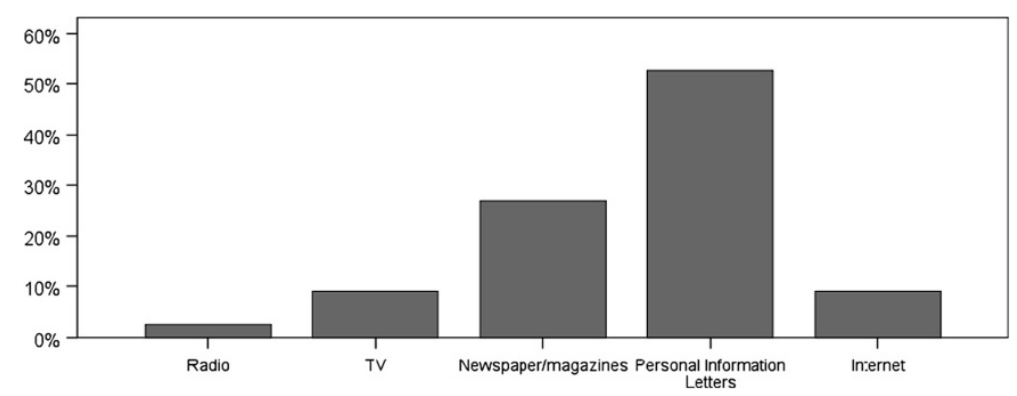

Figure 4 The most suitable method for disseminating information on forest-based bioenergy certification among the Finnish NIPFs $(N=78)$.

Finnish NIPFs in mobilizing energy wood from forests. This was similar to the findings by Leitch [18] from the NIPFs in Kentucky, USA. In Finland, energy wood is generally collected from thinning of small diameter trees and forest residues after logging operations. Therefore, the problem of logistics as considered by the NIPFs was, to some extent, exceptional considering that Finland has a well-developed technology for extracting forest biomass. However, the reason for this could be attributed to the general recommendations that energy wood harvesting should be integrated into the commercial logging operations; otherwise, it is not so cost-efficient to harvest relatively small amount of energy wood from forests [29]. Another possible reason could be that the Finnish NIPFs perceived the logistical arrangement related to energy wood harvesting such as affordability and accessibility to machinery and transport route as inconvenient [30]. A considerable number of the NIPFs remained undecided on the pricing issues as they expressed their lack of information on that matter. In this regard, the findings of this study were similar to the study by Rämö et al. [22], which revealed the Finnish NIPFs' uncertainties concerning market development of energy wood in the future. The NIPFs favored the government to play an important role in removing the current obstacles in the energy wood market. This perhaps indicated that in the first phase, the government could provide with subsidies for small scale harvesting of energy wood and thereby help the market to grow itself in the near future, as it has already been presented in public discussions in Finland.

It was notable to find out that more than one third of the Finnish NIPFs in this study were unaware of the status of their forest estates under the PEFC scheme and another one-fifth informed that their forests were not under such scheme. However, in reality, $95 \%$ of the Finnish forests are PEFC-certified including the forests in Finnish Karelia. The majority of the NIPFs also appeared to be unaware of the Criterion 5 of the PEFC certification in Finland that provides guidance for energy wood harvesting. Not only that, a sizeable chunk of the NIPFs who informed that their forests were under the PEFC scheme was also found to be unaware of the Criterion 5. This reflected a general lack of awareness among the Finnish NIPFs related to the PEFC scheme and the guidelines for energy wood harvesting. Only a small number of the total NIPFs opined those guidelines under the Criterion 5 as useful. Therefore, this lack of awareness of the guidelines related to energy wood harvesting and their lack of usefulness as perceived by the Finnish NIPFs certainly indicates that these issues need to be addressed by the bioenergy actors and policy makers in Finland.

The findings suggested that the Finnish NIPFs would prefer a forest-based bioenergy certification scheme, which is practical and easy to follow. They also indicated that such scheme should improve the market conditions for energy wood and should contribute to protect forest biodiversity. Although a considerable number of the NIPFs considered that the awareness of forest-based bioenergy certification was increasing in Finland, the majority of them also reported their ignorance of that issue. Though Finland has no particular certification scheme for forest-based bioenergy at present as mentioned earlier, it is expected that the developments in Europe and other continents to this direction would have strong impacts on the Finnish energy wood market. Therefore, forest-based bioenergy certification schemes should address the concerns of the NIPFs to obtain their support for an effective implementation of bioenergy certification guidelines and developing a functioning forest bioenergy market. It appeared from the study that the NIPFs considered the private forest owners' associations as the most relevant organizations to disseminate information on forest-based bioenergy certification. In addition, personal newsletters emerged as the most preferred way of disseminating information on forest-based bioenergy certification among the Finnish NIPFs, which was still followed by the regional private forest owners' associations in Finland. In the future, it is possible to use 
more internet-based information dissemination, as the ownerships of forest estates move gradually towards young heirs.

\section{Conclusions}

The results derived from the study might be highly policy-relevant concerning the development of energy wood market and related certification schemes in both Finland and similar countries with high percentages of private forest ownerships. Private forestry has different characteristics in the countries within Europe. Nordic countries such as Finland, Sweden, and Norway have long traditions in private forestry. However, in countries such as Estonia, Lithuania, and Latvia, forest ownership has been transitioning from public to private. Nevertheless, forest-based bioenergy production is expected to play an important role to meet many of these countries' targets under the RED by 2020. Therefore, it will be relevant to understand the opinions of the NIPFs in Finland and other European countries related to supply of energy wood, obstacles in mobilizing energy wood from forests, and their expectations from the future solid biomass-based bioenergy certification schemes. Though the findings of the study might be useful, the sample size of the study was not large enough to be a representative of the larger Finnish and the regional contexts. Therefore, the study findings at best could be regarded as a case study and any generalization must be interpreted with caution. Future studies should consider a nationwide sample from Finland to obtain a broader understanding of the Finnish NIPFs' opinions to the energy wood market and forest-based bioenergy certification issues. Similar studies are also required in the other Nordic and Baltic Sea Region countries where NIPFs can play an important role to supply energy wood in the future.

\section{Additional file}

Additional file 1. Title: Survey instrument used in the study. Description: The survey instrument consisted of 25close-ended items covering the aspects of the respondents' profiles and their opinions and awareness related to energy wood market and forest-based bioenergy certification issues in Finland.

\section{Abbreviations}

C and I: Criteria and indicators; FSC: Forest Stewardship Council; NIPFs: Nonindustrial private forest owners; PEFC: Programme for Endorsement of Forest Certification; RED: Renewable Energy Directive.

\section{Competing interests}

The authors declare that they have no competing interests.

\section{Authors' contributions}

$\mathrm{PH}$ conceived the study, designed the survey instrument, conducted the survey, analyzed the data, and wrote the article. TW participated in the design of the study and commented on the manuscript. QM participated in the design of the study, performed data processing, participated in writing the article. PP participated in the design of the survey instrument and contributed to the writing of the article. All authors read and approved the final manuscript.

\section{Acknowledgments}

The authors are thankful to the two anonymous reviewers for their suggestions, which helped to improve the manuscript substantially. The authors are also thankful to Michael Krug and Aino Martikainen from the Bioenergy Promotion project for their expert comments to improve the manuscript. The authors thank Barnali Sarkar for improving the language of the manuscript. The authors also acknowledge the funding support from the LYY-institute at the University of Eastern Finland. In addition, the authors are grateful to all the survey respondents, the forestry centers of North and South Karelia. Finally yet importantly, the authors acknowledge the funding support by the Bioenergy Promotion project to realize this study.

\section{Author details}

${ }^{1}$ School of Forest Sciences, University of Eastern Finland, Joensuu 80101, Finland. ${ }^{2}$ Toivonkatu 5 as 16, Lappeenranta 53600, Finland.

Received: 6 October 2011 Accepted: 23 August 2012

Published: 5 September 2012

\section{References}

1. Statistics Finland (2010) Total energy consumption 2009. Available at http:// www.stat.fi/til/ekul/2009/ekul_2009_2010-12-10_kuv_001_en.html. Accessed 10 January 2011

2. Metla (Finnish Forest Research Institute) (2009) Finnish Statistical Yearbook of Forestry. Finnish Forest Research Institute, Vantaa, p 452

3. Favada IM (2007) Econometric Models of Finnish Non-Industrial Private Forest Owners' Timber Supply and Timber Stock. Available at http://www. metla.fi/dissertationes/df46.pdf. Accessed 11 September 2010

4. Framstad E, Berglund H, Gundersen V, Heikkilä R, Lankinen N, Peltola T, Risbøl O, Weih M (2009) Increased biomass harvesting for bioenergy effects on biodiversity, landscape amenities and cultural heritage values. Available at http://www.norden.org/en/publications/publications/2009-591. Accessed 11 September 2010

5. Stupak I, Lattimore B, Titus BD, Smith CT (2010) Criteria and indicators for sustainable forest fuel production and harvesting: a review of current standards for sustainable forest management. Biomass Bioenerg 35:3287-3308

6. Martikainen A, van Dam J (2010) Evaluation report of different criteria for sustainability and certification of biomass and solid, liquid and gaseous biofuels - D 4.4.1. Available at http://www.eubionet.net/Getltem.asp? item=digistorefile;243852;1540\&params=open;gallery. Accessed 10 April 2011

7. FSC Forest Stewardship Council (2012) Global FSC certificates: types and distribution (6 August 2012). Available at http://www.fsc.org/facts-figures.19. htm. Accessed 20 August 2012

8. PEFC Programme for Endorsement of Forest Certification (2012) Statistical figures on PEFC certification (updated on 31 July 2012). Available at http:// pefcregs.info/statistics.asp. Accessed 20 August 2012

9. Finland PEFC (2009) Criteria for Certification: Level of Forest Holdings of Individual Owners and Criteria for Group Certification. PEFC Finland, Helsinki

10. Forestry Development Centre TAPIO (Finland) () Harvesting energy wood supports the production of industrial wood. Available at http://www.tapio.fi/ harvesting_energy_wood_supports_the_prod. Accessed 4 October 2011

11. Lattimore B, Smith CT, Titus BD, Stupak I, Egnell G (2009) Environmental factors in woodfuel production: opportunities, risks, and criteria and indicators for sustainable practices. Biomass Bioenerg 33:1321-1342

12. EU Commission (2009) EU directive 2009/28/EC on the promotion of the use of energy from renewable energy sources. Available via http://www. erneuerbare-energien.de/english/renewable_energy/international/ eu_directive/eu_directive/doc/45419.php. Accessed 10 September 2010

13. EU Commission (2010) Report from the commission to the council and the European parliament on sustainability requirements for the use of solid and gaseous biomass sources in electricity, heating and cooling. Available at http://eur-lex.europa.eu/LexUriServ/LexUriServ.do?uri=COM:2010:0011:FIN:EN: PDF. Accessed 15 September 2011

14. Havlik P, Schneider UA, Schmid E, Böttcher H, Fritz S, Skalský K, Aoki K, De Cara G, Kraxner F, Leduc S, McCallum I, Mosnier A, Sauer T, Obersteiner M 
(2011) Global land-use implications of first and second generation biofuel targets. Energ Policy 39:5690-5702

15. Hjulfors LN, Hjerpe K (2010) Sustainable bioenergy production - defining principles and criteria. Bioenergy Promotion, Work Package 3, Task 3.1. Swedish Board of Agriculture and the Swedish Forest Agency, Jönköping, p 24

16. FAO (2010) Criteria and indicators for sustainable wood fuels. FAO Forestry Paper 160. Food and Agricultural Organization of the United Nations, Rome, p 93

17. Gruchy SR, Grebner DL, Munn IA, Joshi O, Hussain A (2012) An assessment of nonindustrial private forest landowner willingness to harvest woody biomass in support of bioenergy production in Mississippi: a contingent rating approach. Forest Policy and Econ 15:140-145

18. Leitch ZJ (2012) Private Landowner Intent to Supply Forest Biomass for Energy in Kentucky. Theses and Dissertations-Forestry. Paper 3, University of Kentucky

19. Markowski-Lindsay L, Stevens T, Kittredge DB, Butler BJ, Catanzaro P. Damery D (2012) Family forest owner preferences for biomass harvesting in Massachusetts. Forest Policy and Econ 14:127-135

20. Shivan GC, Mehmood SR (2010) Factors influencing nonindustrial private forest landowners' policy preference for promoting bioenergy. Forest Policy and Economics 12:581-588

21. Bohlin F, Roos A (2002) Wood fuel supply as a function of forest owner preferences and management styles. Biomass Bioenerg 22:237-249

22. Rämö $A K$, Järvinnen $E$, Latvala $T$, Silvennoinen $H$ (2009) Interest in energy wood and energy crop production among Finnish non-industrial private forest owners. Biomass Bioenerg 33:1252-1257

23. Statistics Finland (2010) Greenhouse gases 2008. Available at http://stat.fi/til/ khki/2008/khki_2008_2010-04-23_en.pdf. Accessed 3 September 2011

24. Wibe $\mathrm{S}$ (2012) Carbon dioxide emissions from wood fuels in Sweden 1980-2100. J Forest Econ 18:123-130

25. Oikari M, Kärhä K, Palander T, Pajuoja H, Ovaskainen H (2010) Analyzing the views of wood harvesting professionals related to the approaches for increasing the cost-efficiency of wood harvesting from young stands. Silva Fennica 44:481-495

26. Lewandowski I, Faaij APC (2006) Steps towards the development of a certification system for sustainable bio-energy trade. Biomass Bioenerg 30:83-104

27. Metinfo (2009) Forest information services. Finnish Forest Research Institute (Metla), Available at http://www.metla.fi/metinfo/tilasto/. Accessed on 10 January 2011

28. Torvelainen J (2010) Environmental influences of small-scale use of fuelwood in Finland - preliminary life cycle observations. Available at http:// www.bioenergypromotion.net/project/publications/environmentalinfluences-of-small-scale-use-of-fuelwood-in-finland-report. Accessed 10 January 2011

29. Kärhä K, Jylhä P, Laitila J (2011) Integrated procurement of pulpwood and energy wood from early thinnings using whole-tree bundling. Biomass Bioenerg 35:3389-3396

30. Tahvanainen T, Anttila P (2011) Supply chain cost analysis of long-distance transportation of energy wood in Finland. Biomass Bioenerg 35:3360-3375

doi:10.1186/2192-0567-2-19

Cite this article as: Halder et al:: Nonindustrial private forest owners' opinions

to and awareness of energy wood market

and forest-based bioenergy certification - results

of a case study from Finnish Karelia. Energy, Sustainability and Society 2012 2:19.

\section{Submit your manuscript to a SpringerOpen ${ }^{\circ}$ journal and benefit from:}

- Convenient online submission

- Rigorous peer review

- Immediate publication on acceptance

- Open access: articles freely available online

- High visibility within the field

- Retaining the copyright to your article

Submit your next manuscript at $\gg$ springeropen.com 